\title{
Religion and Water Preservation: Tradition Studies Nahdhatul Ulama (NU) in Earth Alms in Daren Village Nalumsari Jepara
}

\author{
Alamsyah $^{*}$ \\ Department History, Faculty of Humanities, Diponegoro University, Semarang - Indonesia
}

\begin{abstract}
Religion and water preservation is seen in earth alms activity of Nahdhatul Ulama (NU) community in Daren village in Jepara. Earth alms is one of missionary endeavour media in order to bring people and the living environment closer. The activity that is held by NU community Daren Nalumsari Jepara is an effort to foster a sense of love for the preservation of natural resources. This activity, that carry the values of local wisdom is held in a sendang (spring). Beside the local wisdom, this activity is loaded with religious teachings and as an effort to bring closer the people to preserve water resources. Spring preservation in the earth alms had an important meaning and as a representation of people's lives that cannot be separated with water in their everyday life.
\end{abstract}

Keywords. NU, Environment, Earth Alms, water, Spring

\section{Introduction}

Islam in Java has its own uniqueness compared to Islam in other regions. Islam in Java has unique characteristics, where the influence of Islamic culture which is assimilated into Javanese culture strengthens more the social harmony of the community [1]. Mutual acculturation between Islam and Javanese culture methodologically as something that allows its existence to be accommodated. It can be seen in the principles of fiqh which states that "al- 'adah muhakkamah" (tradition can become law) or the principles of "al-'adah syariatun muhkamah" (tradition is a sharia that can be made as law). Not all Javanese Culture can be made law because it might be not accordance with Islam. The Javanese culture elements that are not suitable are replaced or adjusted according to the mission of Islam as human liberator with monotheism spirit [2].

Nahdlatul Ulama (NU) is the largest Islamic organization in Indonesia that accepts the concept Javanese and Islamic culture acculturation. In this context, NU seeks to preserve culture as an infrastructure which there are Islamic sharia values on it with cultural basis [3].

*Corresponding author: alam_mahir@yahoo.com 
NU community in various regions in Java are still holding activities or Javanese culture activities that are adapted to Islam teachings, one of which is earth alms.

The earth alms which held by some Javanese people can also be associated with efforts to preserve the living environment. NU also has a great commitment to environmental preservation efforts, one of which is through missionary endeavour with a cultural approach. This activity invites the community to strive in preserving the environment (bi'ah strive) which is still referring to aqidah ahlussunah wal jamaah in detail to apply the values of tasawuth (moderate), tasamuh (tolerant), tawazun (balanced), and amar ma ' ruf nahi munkar. NU also developed the concept of environmental fiqh (Fiqih al bi'ah) which is expected to be able to return humans to love their environment, so that the living environment cannot be separated from the responsibility of humans who have faith and virtuous character [4].

The NU community in Daren Village, Nalumsari Subdistrict, Jepara holds earth alms activities in accordance with Islamic teachings. The activity is held by praying together as well as carnival of Tumpeng and mountains of crops that is held in Sendang Bidadari complex. In its implementation, this activity has been changed and adjusted to the Islamic teachings, so it does not have any contradiction with Islam [5]. The activity that is held in Sendang (spring) can be interpreted as an effort to get closer to nature and maintain the preservation of water sources in Daren village.

\section{Method}

This research is a qualitative study using historical methods consisting of heuristics, criticism, interpretation, and historiography [6]. Heuristics was the process to find primary and secondary sources [7]. Primary sources were obtained from observations, government or individual archives, activities photos, and interviews with the people who hold earth alms activity. Interviews were conducted to explore the process and meaning of earth alms activities in Daren Jepara. Secondary sources are taken from relevant writings such as books, journals and other literature. Secondary sources can be obtained from libraries, personal collections, and internet. The available sources are then criticized and interpreted. The analysis results above are then linked and reconstructed into an article about Religion and Water Sources Preservation: NU Tradition in Earth Alms in Daren Nalumsari Jepara.

\section{Results and Discussion}

\subsection{Earth Alms in NU perspective}

Earth alms in terms of Javanese culture is a ceremony performed to give offerings to ancestors' spirit who have passed away, and when they are still alive it is believed by the villager community that the person is the village founder [8]. This earth alms can attract the sympathy of the spirits who dwell in a haunted place. At a certain time, this place is served with offerings in the form of snacks and flowers. The offerings are held to support their belief of spirits power existence such as supernatural beings, ghost, and jinn that rulling or staying in those places so that they do not interfere with the safety, tranquility, and happiness of the concerned family [9].

In its development, earth alms is experiencing a substantial shift. Based on NU's view, earth alms interpreted as a gratitude expression to Allah SWT who has given abundant natural gifts. In Qur'an, Surah Ibrahim: 7 says that "and (remember) when your Lord proclaimed; "If you are grateful, I will surely increase you (in favor), but if you deny (My favor), indeed, My punishment is severe." (QS. Ibrahim: 7) [10]. 
In this context, earth alms is interpreted as an effort to keep the ancestors tradition. Javanese religion, Hinduism, and Buddhism have been existed long before Islam arrived in this archipelago. Walisongo as the Islamic propagator allowed the old Javanese traditions to keep running, but these traditions were filled with Islamic values. The traditions implementation must also not be contradicted with Islamic Sharia. As found in Ahkamul Fuqaha NU which states that "The first person who asked for protection from Jinn was a man from Hanifah family in Yemen, then it spreaded in Arabia, after Islam came, then protection from Allah SWT replaced the protection asked from Jinn." [11]. The current implementation of earth alms does not refer to spirits such as supernatural beings, ghost, and jinn who are are rulling the place but it is as a gratitude expression to Allah SWT and the activity is filled with Islamic values.

\subsection{Earth Alms: Culture and Water Source Relations}

\subsubsection{Sendang Bidadari Legend}

Earth alms in Daren village Jepara is held at Sendang Bidadari. The existence of Sendang Bidadari is always associated with Jaka Tarub legend. Based on an oral story, it is said that Daren people believed in relationship between Sendang Bidadari and Jaka Tarub legend. In his odyssey, Jaka Tarub who was a young man from Mataram Kingdom was attracted to an angel. When he arrived at a village, now called Daren Village, he met a widow named Mbok Randha who later adopted Jaka Tarub as her child [12].

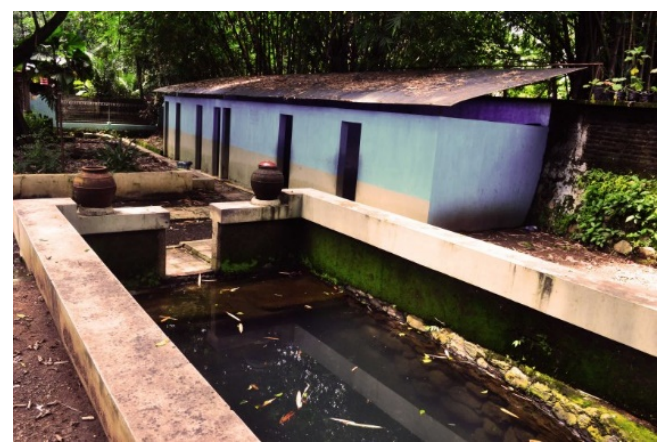

Documentation: darennalumsari.wodpress.com

Fig. 1. Sendang of Bidadari [24]

One day, when Jaka Tarub was on a hill, he heard a bird chirping. Jaka Tarub tried to catch the bird. When he was about to catch the bird, he heard the sound of water splashing from a people who was taking a bath. Jaka Tarub saw there were several angels bathing in a spring (now called Sendang Bidadari). He was curious and took one of the angel's scarf and turned out that it belonged to an angel named Nawang Wulan [13]. After bathing, Nawang Wulan searched for her scarf but she could not find it. As the result, Nawang Wulan cannot come back to her home without the scarf. Nawang Wulan then made a promise that if there was a man who helped her she would make him as her husband, if there was a woman who helped her then she would make her as her sister. Nawang Wulan, who had been left by her friends, met Jaka Tarub. Nawang Wulan was married to Jaka Tarub and had a daughter named Nawangsih [14]. This story become the basis of the earth alms procession started from Sendang Bidadari. 


\subsubsection{Earth Alms Procession: Tumpeng and Crops Carnival}

Tumpeng and Crops Carnival Activity in in Daren, Namumsari, Jepara are held every Hijriyah New Year's Eve. This activities are held in Sendang Bidadari Complex, Daren Village. This activity is included in the earth alms activity which have been existing far before Islam entered the archipelago. Although Tumpeng and Crops Carnival in Daren have been existed far before Islam arrival, but this activities are still held today with the adjustment and additional values of Islamic sharia [15].

This activity is preserved by NU community in Daren village, in which the majority of the resident are NU community. To preserve these activities, several NU organizations actively become the initiators and implementers of the Tumpeng and Earth Alms Carnival activities. Those organizations are NU Student Association (IPNU), NU Women Student Association (IPPNU), and Fatayat NU. The activities that are held routinely every year has an aim to get the people closer to Allah subhanahu wa ta'ala and bring the people closer to local traditions. NU communities' contribution in this activities are big enough so that it can be held every year [16].

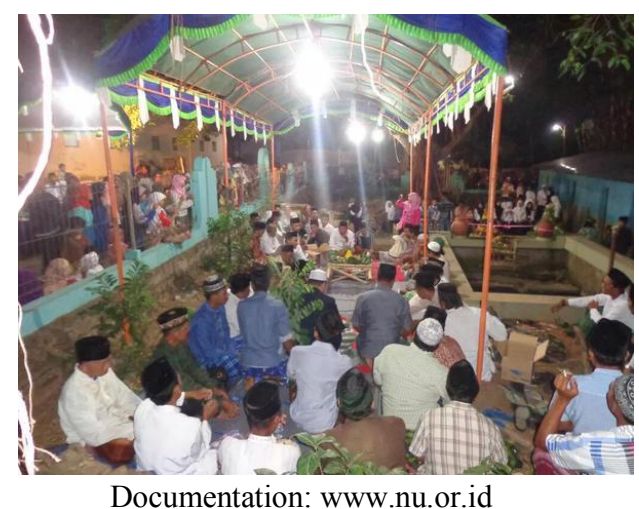

Fig. 2. Prayer Together activity in Tumpeng and Crops Carnival series of events in Sendang of Bidadari Complex

The activity began with prayer together led by the village cleric. This activity is held in Sendang Bidadari complex. After prayer, the next procession is Tumpeng and Crops Carnival. The Carnival starts from Sendang Bidadari complex, then is paraded by the residents around the village. The end point of Tumpeng and Crops Carnival procession is at Daren Village Hall. [17]. In this village hall some people who did not take part in the carnival activities also prayed and hoped for God's blessing through Sendang Bidadari water so that they would always be healthy and get much kidness [18].

\subsubsection{Earth Alms and Water Preservation}

There is a fairly close relationship between earth alms with water conservation efforts. In ecology concept, humans are always related to the environment. In Islamic ecological dialectical theory, there is a dialectical process between Islamic religious spiritual values and ecological values. In Islamic ecological dialectical theory, there is a dialectical process between Islamic religious spiritual values and ecological values. The dialectical process that happened is carried out through three stages, they are internalization stage, objectification stage, and externalization stage [19]. Islam implicitly teaches people to know, and realize the importance of protecting everyday environment. Islam teaches the people to care about their environment. That any damage to nature, and environment will finally have long-term adverse effects on human beings themselves [20]. As written in Surah Ar-Rum verse 
41"Mischief has appeared in the land and the sea because of what the hands of the mankind have earned, that Allah may make them taste a part of that which they have done, so that they may return (turn to Allah)"

Based on that reasons, it is natural that NU as the largest Islamic community organization in Indonesia, including Jepara, has the obligation to save environment from the damage. Activities held in the form of missionary programs that lead to environmental stewardship including water resources [21]. NU's commitment to environmental preservation is reflected in three main programs they are organizing social and environmental fiqh concept, discuss some themes of environmental crisis in bahtsul masail (a discussion forum between Islamic scholars in NU Islamic boarding house area), and make an environmental institution called Institute for Disaster Management and Climate Change of Nahdlatul Ulama (LPBINU) [22].

The implementation of environmental preservation efforts is reflected in the earth alms activities in Daren Village. Through the tradition at Sendang Bidadari, NU community in Daren have maintained the environmental preservation regularly every year. This tradition shows that the community has preserved the environment in the form of village water source preservation in Sendang Bidadari. This spring is a very important water source for the community, especially Daren residents. Water is a very valuable asset and needs to be preserved. Especially with the tendency of decreasing water source and increasing water needs [23].

Earth alms activities that held in sendang or spring certainly have symbolic meaning. People who participate in earth alms activities will be closer to nature and love the environment around them, especially the spring in Sendang Bidadari. When the water in Sendang is dry, damaged or used up, the meaning of the procession will be diminished. Some people still consider that the place where the earth alms activity held is as a sacred place. Sendang Bidadari which is a sacred place will always be maintained so that the spring in Sendang is protected from damage. Through the earth alms activities that centered in Sendang Bidadari, the community will avoid doing somthing that can damage the place that are considered as sacred place. The earth alms activity in Daren is very beneficial for the spring preservation in Sendang Bidadari. The spring is very useful for the surrounding people for household needs as well as worship needs at the Mosque and Islamic boarding house which are not far from Sendang Bidadari.

\section{Conclusion}

The Earth Alms activity is a legacy from the Javanese people that is still being held. In its implementation, the Alms Earth activity has changed its function of being a da'wah media for NU in spreading Islam. This is in line with NU's commitment to environmental sustainability by utilizing the tradition of earth alms in Daren village Jepara. Through the tradition that can bring people closer to the environment. Earth alms activities at Sendang Bidadari Complex have the meaning that Sendang is a water source that is important for life. The environmental preservation especially the water resources preservation in Sendang Bidadari can keep the tradition that is regularly held every year. With this tradition, the community will guard this place and will not dare to damage the water source because it will bring disaster. The water resources preservation in Sendang Bidadari is very useful for community life and worship activities in Daren Village.

\section{Acknowledgement}

The research is funded by DIPA Diponegoro University in 2020 budget year. 


\section{References}

1. Khalil, Ahmad., Islam Jawa, Sufisme dalam Etika dan Tradisi Jawa (2008)

2. Fathani, Abdul Halim., Pergolakan Islam dalam Tradisi Jawa, www.nu.or.id/post/read/13558/

3. Erdianto, Kristian., Cara NU Menjaga Nilai-Nilai Islam Melalui Jalan Kebudayaan, Kompas, 1 Februari 2017.

4. Romdloni, M. Afwan dan M. Sukron Djazilan., "Kiai dan Lingkungan Hidup: Revitalisasi Krisis Ekologis Berbasis Nilai Keagamaan di Indonesia”, Journal of Islamic Civilization, Volume 1, Nomor 2, Oktober 2019

5. Wafa, Yusrul., Satu Suro, Ada Tradisi Kirap Tumpeng dan Hasil Bumi di Jepara, www.nu.or.id/post/read/62796/

6. Garraghan, Gilbert, A Guide to Historical Method (1947)

7. Herlina, Nina, Metode Sejarah (2008)

8. Geertz, Clifford., Agama Jawa: Abangan Santri Priyayi dalam Kebudayaan Jawa (2013)

9. Amin, Darori., Islam dan Kebudayaan Jawa (2000)

10. Al-Qur'an, Yayasan Penyelenggaraan Penerjemah., Al-Qur'an dan Terjemahnya

11. Miri, Muhammad Djamaluddin dan Ahkamul Fuqaha., Solusi Problematika Actual Hokum Islam, Keputusan Muktamar, Munas, Dan Kombes NU, terj (2007)

12. Effendi, Haris., Mandi Air Abadi di Sendang Bidadari, www.metrojateng.com/

13. Effendi, Haris., Mandi Air Abadi di Sendang Bidadari, www.metrojateng.com/

14. Effendi, Haris., Mandi Air Abadi di Sendang Bidadari, www.metrojateng.com/

15. Parwito, Malam 1 Suro, Warga Ritual di Sendang Petilasan Joko Tarub, www.merdeka.com/peristiwa/

16. Wafa, Yusrul., Satu Suro, Ada Tradisi Kirap Tumpeng dan Hasil Bumi di Jepara, www.nu.or.id/post/read/62796/

17. Wafa, Yusrul., Satu Suro, Ada Tradisi Kirap Tumpeng dan Hasil Bumi di Jepara, www.nu.or.id/post/read/62796/

18. Ibda, Hamudulloh., Tradisi Suronan Warga Pantura, www.alif.id/read/hamidulloh$\underline{\text { ibdal }}$

19. Mardhiah, Izzatul; Rihlah Nur Aulia; dan Sari Narulita., “Konsep Gerakan Ekoteologi Islam", Jurnal Studi Al-Qur'an Vol. 10, No. 1, Tahun. (2014)

20. Syafrilsyah dan Fitriani, "Agama dan Kesadaran Menjaga Lingkungan Hidup", Substansia, Volume 16, Nomor 1, April 2014

21. Mardhiah, Izzatul; Rihlah Nur Aulia; dan Sari Narulita., "Konsep Gerakan Ekoteologi Islam”, Jurnal Studi Al-Qur'an Vol. 10, No. 1, Tahun. (2014)

22. Muchlishon, Tiga Kontribusi Utama NU terhadap Kelestarian Lingkungan Hidup, www.nu.or.id/post/read/97065/

23. Siswadi, Tukiman Taruna, dan Hartuti Purnaweni, "Kearifan Lokal dalam Melestraikan Mata Air", Jurnal Ilmu Lingkungan volume 9 (2), (2011)

24. Desa Daren Nalumsari. Wisata Sendang Bidadari.darennalumsari.wodpress.com 